\title{
Landscape archaeology and urbanism at Meninx: results of geophysical prospection on Jerba (2015)
}

\section{Stefan Ritter, Sami Ben Tahar, Jörg W. E. Fassbinder \& Lena Lambers}

This paper presents the results of the geophysical prospection conducted at the site of Meninx (Jerba) in 2015. This was the first step in a Tunisian-German project (a cooperation between the Institut National du Patrimoine, Tunis, and the Institut für Klassische Archäologie der Ludwig-Maximilans-Universität München), the aim of which is to shed light on the urban history of the most important city on the island of Jerba in antiquity.

Meninx, situated on the SE shore of the island (fig. 1), was the largest city on Jerba during the Roman Empire and eponymous for the island's name in antiquity. ${ }^{1}$ The outstanding importance of this seaport derived from the fact that it was one of the main production centers of purple dye in the Mediterranean. ${ }^{2}$ With the earliest secure evidence dating to at least the Hellenistic period, Meninx saw a magnificent expansion in the 2nd and 3rd c. A.D. It was inhabited until the 7 th c. when the city was finally abandoned. ${ }^{3}$

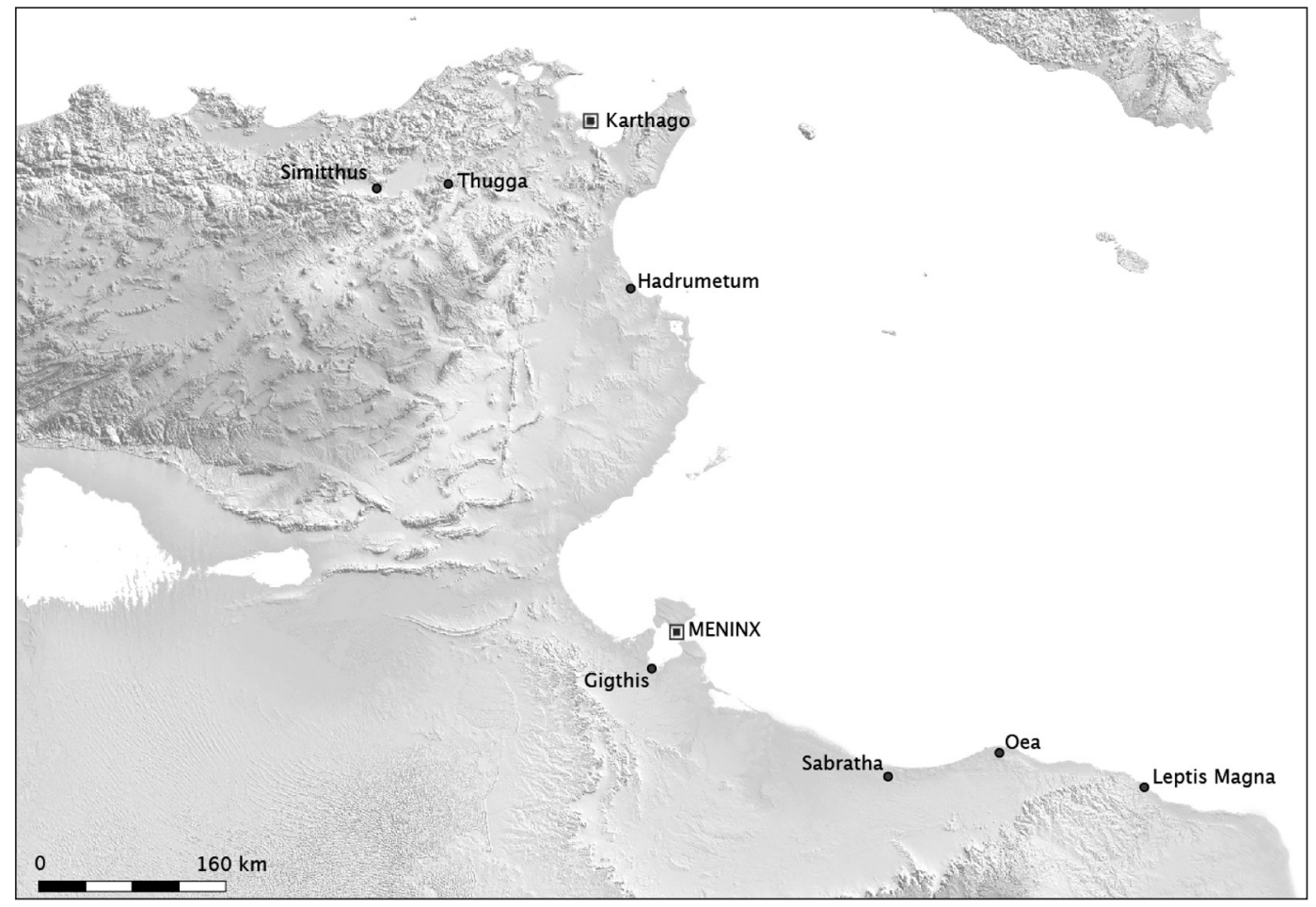

Fig. 1. Meninx in its N African context (P. Scheding).

1 For a list of the ancient sources on Jerba and the city of Meninx, see A. Drine, E. Fentress and R. Holod (edd.), An island through time: Jerba Studies 1. The Punic and Roman periods (JRA Suppl. 71, 2009) 37-43 with Table 3.1 (with earlier bibliography), henceforth cited as Jerba Studies 1; cf. A. Agus and R. Zucca, "Meninx-Girba nelle fonti letterarie ed epigrafiche," L'Africa romana 14 (2002) 1919-54.

2 Plin., NH 9.127.

3 For the current state of research on the urban history of Meninx see Jerba Studies 1, 75-76 (for the 


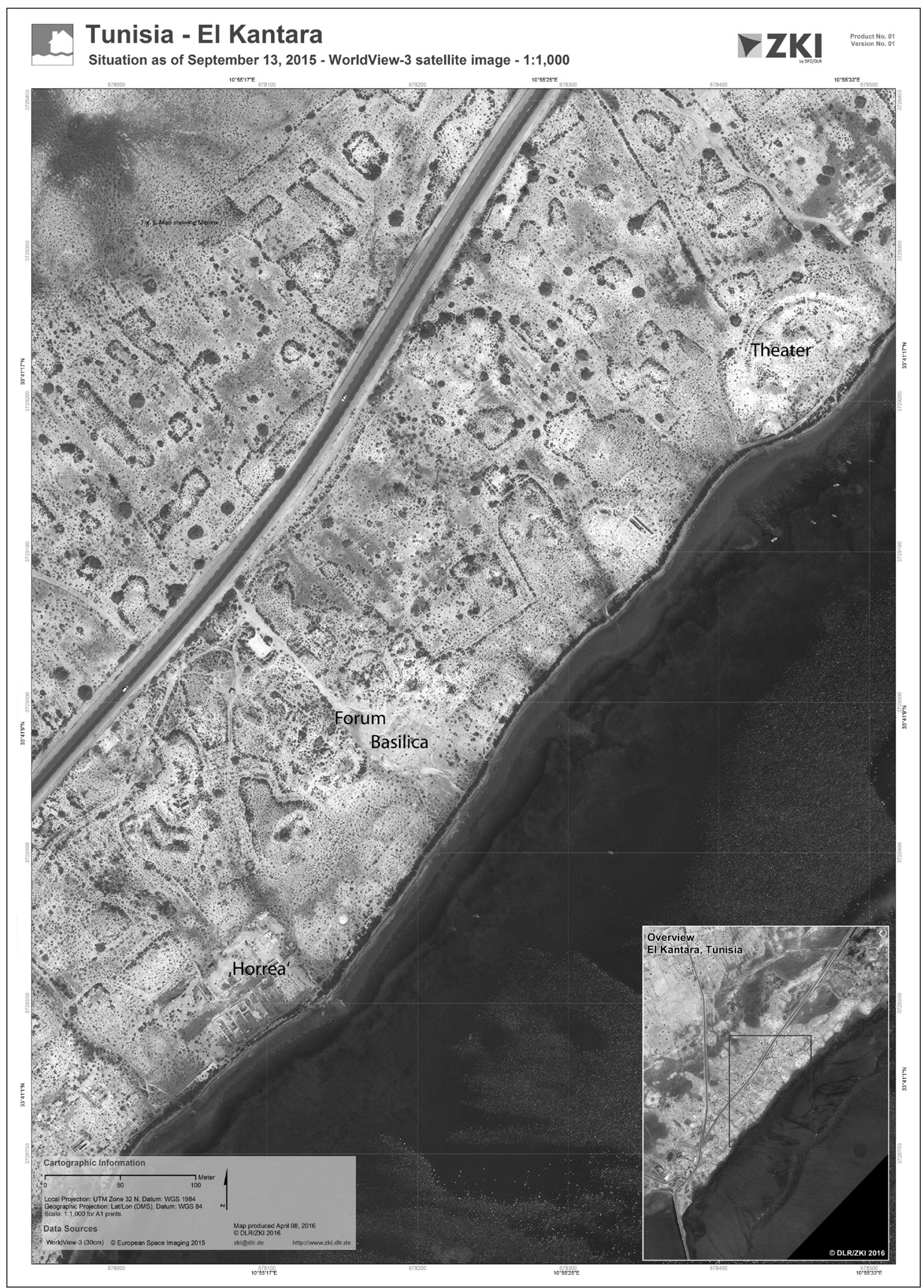

Fig. 2. Meninx, air photograph (Deutsches Zentrum für Luft-und Raumfahrt - Zentrum für Satellitengestützte Kriseninformation, April 8, 2016). 


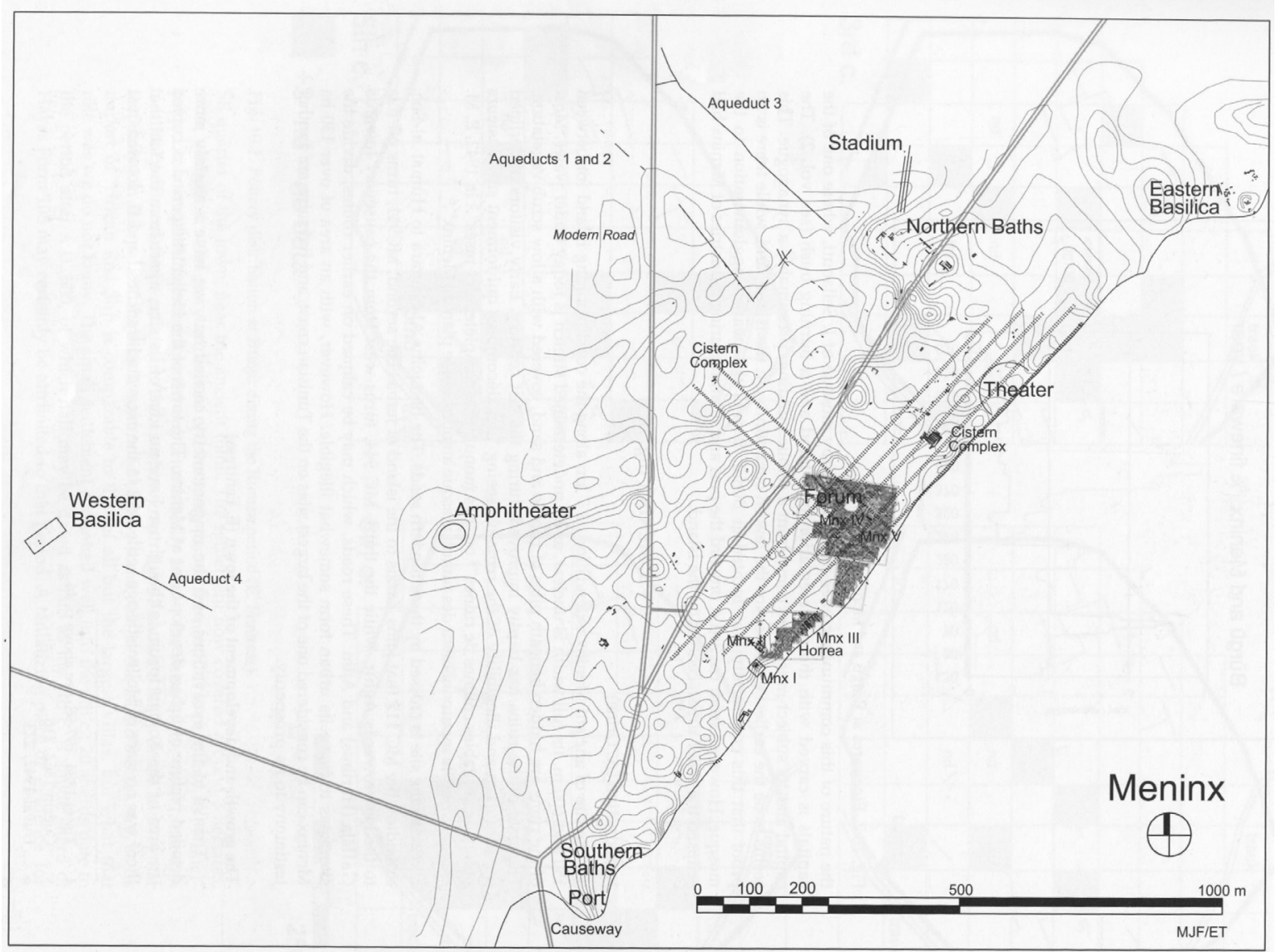

Fig. 3. Meninx, plan of the city created in 2000 (after Jerba Studies 1, fig. 10.3).

The layout of the city is only partially known from a few isolated buildings (fig. 2 ). ${ }^{4}$ On the coast at the northeast is a large theatre, the shape of which can be recognized beneath a high hill of débris. Farther south, the Forum is attested by the remains of a huge civic basilica, as well as by numerous architectural blocks originating from this basilica and from several temples surrounding the square. There are also the ruins of an amphitheatre, a huge bath complex, and the modest remains of some other buildings.

Until recently, archaeological research was confined to some sporadic and isolated excavations. ${ }^{5}$ Systematic archaeological research began only in the 1990s, with a survey project conducted on the island between 1996 and 2000 (directors: A. Drine, E. Fentress and R. Holod). The results relating to the Punic and Roman periods were published in a monograph in 2009, which is the indispensable basis for anyone studying Meninx. ${ }^{6}$ Even if the focus of that survey project was directed at the whole island and not just at Meninx itself, exploration of the city was conducted through a number of investigations and was the focus of a surface survey. Apart from an intensive pottery survey, exploration of the Forum area, excavation of the 'horrea' and some small trenches, in 2000 a larger area around

Hellenistic period), 133-74 (Roman and late antiquity). 
the Forum was explored by means of a fluxgate gradiometer survey (marked on fig. 3). ${ }^{7}$ The magnetometry data revealed the structure of the civic basilica, some walls of other buildings surrounding the Forum, and, farther southwest, a macellum covering an area of roughly $60 \times 60 \mathrm{~m}$. The results demonstrated that, if one overlooks the uneven terrain, the conditions for magnetometry are quite favourable, offering a high magnetic contrast at the site.

The impressive results of the Tuniso-American work at Meninx inspired S. Ben Tahar and S. Ritter to initiate a new project at the site, which extends for more than $1.5 \mathrm{~km}$ along the coast and runs inland up to $500 \mathrm{~m}$. We conceived the current project in 2013, and decided to begin with a large-scale geophysical prospection in order to gain insight into the internal urban organization. To explore the centre of the Roman city first without overlapping too much with previous investigations, we decided to begin our prospection northeast of the 'horrea', which had been excavated by Drine between 2000 and $2004 .{ }^{8}$ Since the nearby Forum had been only partially surveyed with the magnetometer in 2000, we chose first to investigate the wider Forum area which, according to the evidence recovered by the Tuniso-American project, was already occupied in the Hellenistic period. ${ }^{9}$ This first magnetometer survey was conducted in October 2015 by Fassbinder and his assistant L. Kühne. Within 10 days we surveyed the full strip between the present coastline and the modern coastal road, a total area of $c .600 \times 200 \mathrm{~m}$. This area encloses the nucleus of the Roman city, from the SW periphery of the Forum to the theatre in the northeast.

\section{The geophysical prospection}

\section{Methods}

For non-destructive and large-scale archaeological prospecting a multitude of different ground-based methods are available. The most common are:

1. Magnetometer prospecting (a "passive" method)

2. Radar prospecting (an "active" method)

3. Resistivity prospecting (an "active" method).

Magnetic prospecting, a "passive" method, measures a latent existing magnetic field, whereas the other methods, radar and resistivity prospecting, which are "active", can be regarded as suitable for searching for stone structures. They are not affeected by electromagnetic and magnetic objects nearby and can therefore be applied even inside a building. The application of these methods is time-consuming, however, requiring intensive and sophisticated data-processing in order to display the resulting data. Radar and resistivity prospecting methods are affected by several conditions: saline and clayey soils dramatically dampen the penetration of the radar waves, while the rough, uneven topography at Meninx makes a high-resolution radar survey utterly impossible. Resistivity prospecting is not only the most time-consuming prospection method but is also limited by the poor conductivity of the very dry and sandy topsoil layers at this particular site. Magnetometer prospection, therefore, remains the most suitable method for large-scale but high-resolution prospection of archaeological sites in an open landscape or in any other environment.

7 For investigations in the Forum area, ibid. 32-33 and 135-49 with fig. 10.3 (plan of Meninx) and fig. 10.5 (magnetometry of the Forum area).

8 Ibid. 222-29.

$9 \quad$ Ibid. 133-35. 
The uneven conditions of the terrain at Meninx, however, pose a great challenge. The area is partly overgrown by bushes up to $50 \mathrm{~cm}$ high and in some places is covered by stones or heaps of ruins up to 3-4 m high. These conditions require a magnetometer equipment and a configuration that corrects errors caused either by tilting the sensor or by changing its distance from the ground.

\section{Prospection by magnetometer}

To achieve the highest possible sensitivity combined with a maximum speed of prospection, we chose a cesium total field magnetometer (Scintrex SM4-G Special). We set up the instrument with the so-called "duo-sensor" configuration, by which we mount the probes on a wooden frame and carry them in zigzag-mode $c .30$ $+/-10 \mathrm{~cm}$ above the ground (fig. 4 ). The profiles of our $40 \times 40 \mathrm{~m}$ grid were oriented $\mathrm{E}-\mathrm{W}$ in order to minimize interactions of the magnetometer probes with the electronic parts and batteries of the device.

The sampling frequency of the magnetometer (sampling rate is 10 measurements

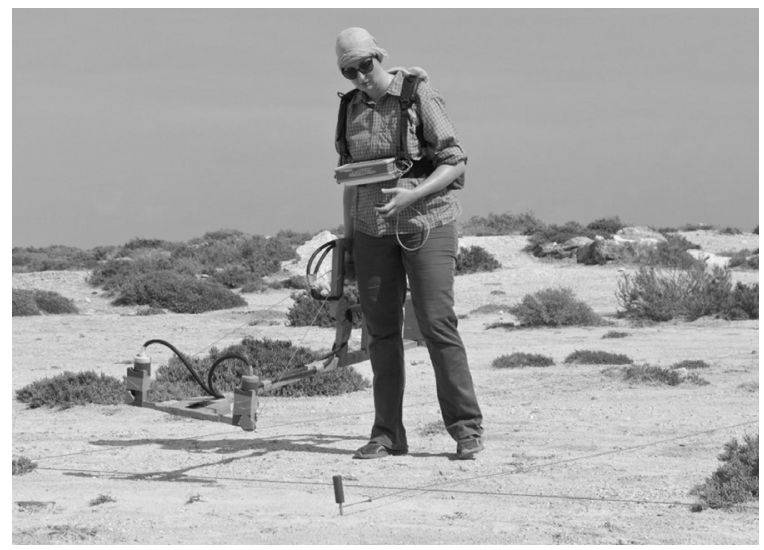

Fig. 4. Magnetometer prospecting at Meninx with the handheld "duo-sensor" cesium magnetometer (J. Fassbinder). per second) allows the survey of a 40-m profile in less than 30 seconds, maintaining the spatial resolution of the data of $c .10-15 \mathrm{~cm}$. Every $5 \mathrm{~m}$, in parallel to the magnetic data, a manual switch sets a marker. This helps us to obtain the best and most exact interpolation of data (to $25 \times 25 \mathrm{~cm}$ ) during the subsequent processing work in the laboratory. At that time we remove the slight linear changes in the daily variation of the geomagnetic field by means of a reduction filter and calculate the mean value of the $40-\mathrm{m}$ profile. In addition, we calculate the mean value of all data from the $40 \times 40 \mathrm{~m}$ grid and subtract this value from the survey data. We assume that the variation of the Earth's magnetic field during the measurement of one $40-\mathrm{m}$ profile follows a linear increase or a linear decrease of the intensity of the Earth's magnetic field. Thus it is possible to eliminate this variation for each traverse line by a reduction to the mean line value. This procedure filters apparent linear structures running parallel to the profile. Alternatively, in magnetically 'quiet' areas, it is also useful to calculate the mean value of the whole $40 \times 40 \mathrm{~m}$ grid and use this value for further data processing, as described above. To create discrete field values, we use a re-sampling program, setting the data to a sampling interval of $25 \times 25 \mathrm{~cm}$. Through using this procedure, the difference between the measurement of both the magnetometer probes and the theoretically-calculated mean value of the Earth's magnetic field was obtained. This intensity difference shows the apparent magnetic anomaly, caused by the magnetic properties of the archaeological structure, the soil magnetism and the geology. To cancel the natural micro-pulsations of the Earth's magnetic field, we apply a band pass filter in the hardware of the magnetometer processor. Normally, more than $98 \%$ of the magnetometer data in a $40-\mathrm{m}$ grid on an archaeological site vary within the range of $\pm 20 \mathrm{nT}$ from the corrected mean value of the geomagnetic field. We ascribe the stronger anomalies to burned structures, to lightning strikes, or to pieces of iron containing slag or iron rubbish; in situ burning, pieces of iron, and traces of lightning strikes are all easily distinguishable not only by their different direction of magnetic dipole anomalies but also by their high intensities $(> \pm 50 \mathrm{nT})$.

The application of the optical pumped cesium-magnetometer Smartmag in the so-called duosensor configuration allows one to set the reference value (e.g., the virtual gradient of the Earth's magnetic field) to infinity, so that the magnetic anomalies are recorded with their full intensity (fig. 5). The advantage of this configuration is rather obvious. The resulting data have a higher magnetic intensity, hence give more information on the buried features and also on deeper parts of the archaeological layers and structures. On the other hand, the data can be 'disturbed' by near-surface geological features and especially by technical facilities (such as power lines) nearby. We removed these disturbances by applying a high-pass filter to the data. The instrument itself allows us to measure the total Earth's magnetic field by an intrinsic sensitivity of \pm 10.0 Picotesla, with a sampling rate 


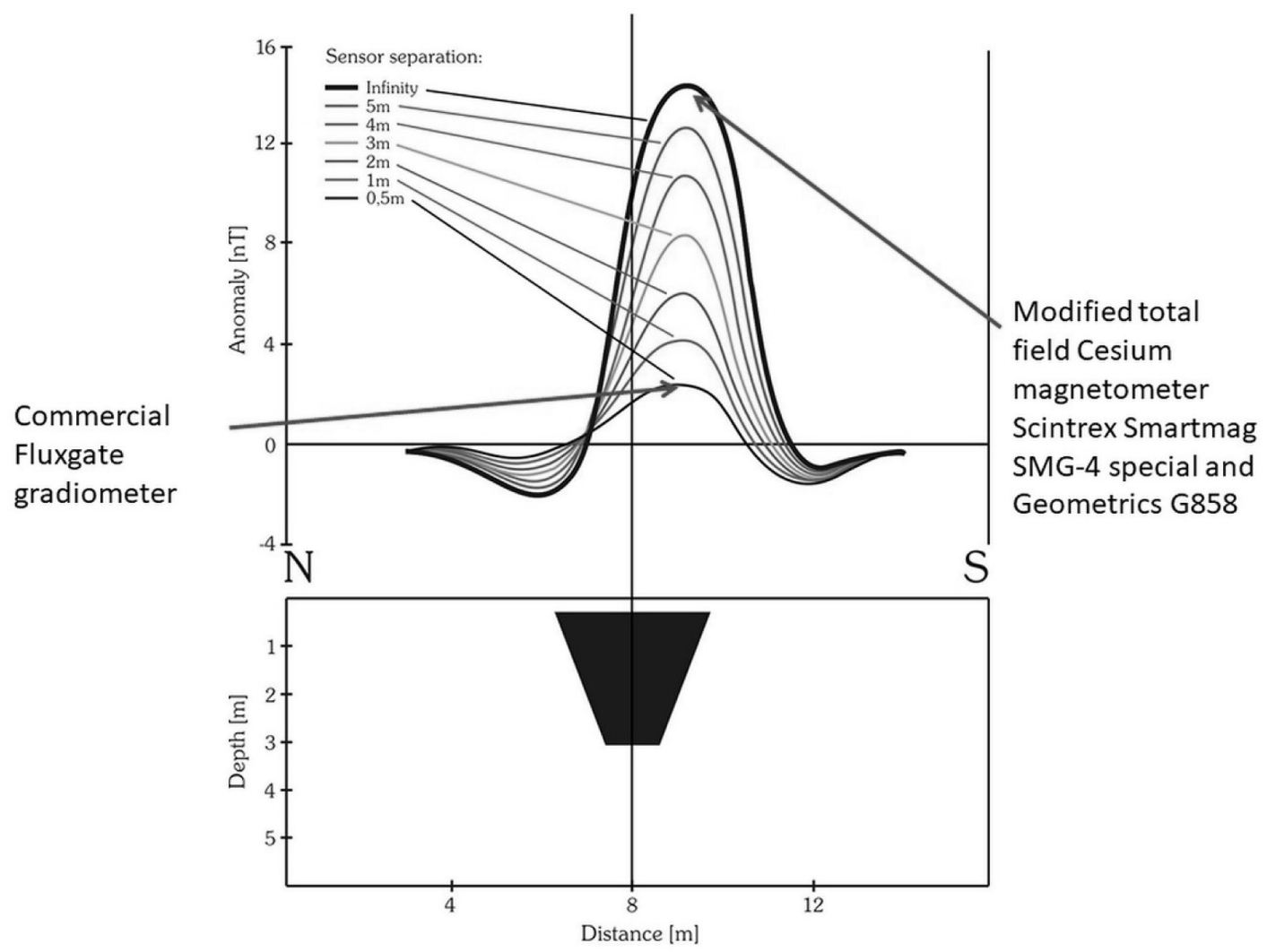

Fig. 5. Dependence of the intensity of a magnetic anomaly of a typical prehistoric feature, such as a ditch, on the sensor separation (gradient) of a commercial fluxgate gradiometer (50-65 $\mathrm{cm}$ gradient) and a total field cesium magnetometer with a virtual gradient of $>5 \mathrm{~m}$.

of 10 measurements per second (for comparison, the daily fluctuations of the Earth's magnetic field at Meninx in October 2015 varied within the range of $47610 \pm 30.0 \mathrm{nT}$ ). The data were stored as binary files on the read-out unit, then downloaded to a Panasonic Toughbook and unpacked to ASCII data. For image processing and further treatment, the data were resampled and then visualized by the programs Geoplot (Geoscan Ltd., UK) and Surfer (Golden Software, USA). The visualization as a grey-scale image (magnetogram) allows us to trace even the smallest anomalies that originate from the shade of single posts and palisades beneath the surface. The application of a high-pass filter removes the deeper, mainly geological features and provides supplemental information on the type of the anomalies. After this procedure, the results were displayed by a second magnetogram image.

For the interpretation, we try to classify the findings:

a) by the shape of the feature;

b) by the intensity of the magnetic anomaly;

c) by the direction and intensity of the remanent magnetization; and

d) by the induced magnetization (volume magnetic susceptibility).

Point (a) is based on archaeological knowledge and points (b-d) are based on the theoretical background of applied geophysics and on a knowledge of rock magnetism and supplementary susceptibility measurements. ${ }^{10}$

The topographic conditions at the site were rather difficult due to bushes, hard scrubs, steep hills covering ruins, and débris. Since we had no other limitations (e.g., modern field 
boundaries), we staked out our $40 \times 40 \mathrm{~m}$ grid on a N-S orientation and measured the location of the stakes by GPS individually. We marked the direction of profiles by plastic cords set at a distance of $2 \mathrm{~m}$ to guarantee an exact sampling density of 12.5 x $50 \mathrm{~cm}$ (see fig. 4).

\section{Results}

The building structures beneath the ground were visualized as a greyshade plot in 256 greyscales with dynamics of $\pm 1-4 \mathrm{nT}$ from white to black (fig. 7). Compared to other Roman sites
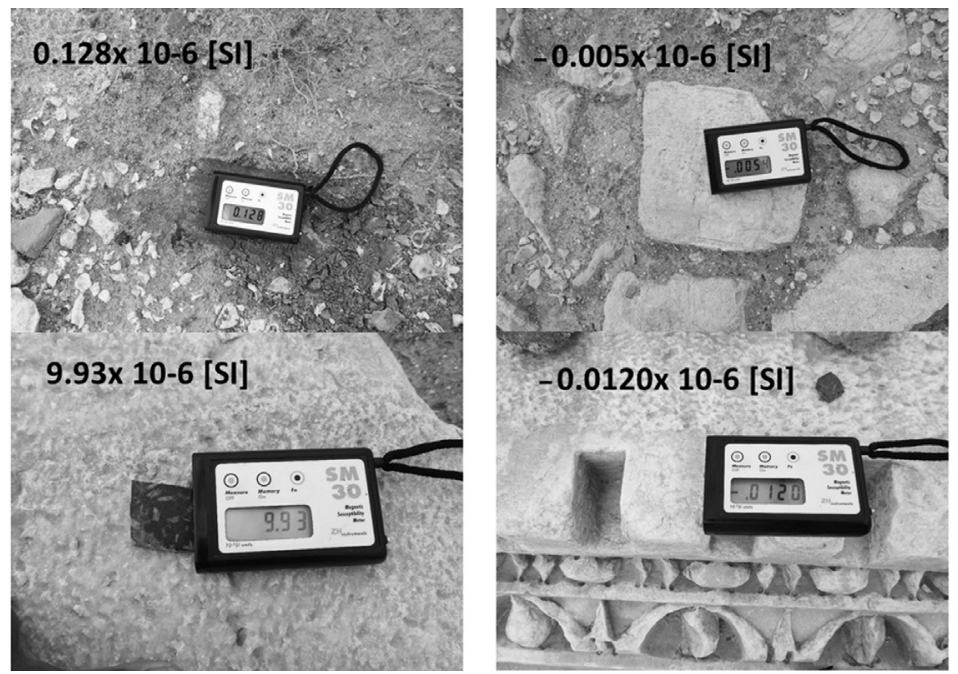

Fig. 6. Meninx, in situ magnetic susceptibility measurements, done by a handheld Kappa-meter SM30 (Zh-Instrument). Some typical kappa values from the site (clockwise from top left): topsoil, sandstone and marble (negative), stone slab.

(e.g., Roman forts in Bavaria or the city of Pompeiopolis where we measured magnetic anomalies of up to $30-50 \mathrm{nT}^{11}$ ), the magnetometer values are extremely low. This was already indicated by the average magnetic susceptibilities of the topsoil and the subjacent sediment, which were comparatively low (values range from $2 \times 10^{-7}$ to $2 \times 10^{-6}$ [SI] units: see fig. 6). Nevertheless, the resulting magnetogram displays an image with high contrasts (fig. 8 in colour). Especially in the flat areas and mostly close to the sea, the features show up through a great magnetic contrast (see the blue zone in fig. 8). Here we assume very shallow foundation walls and buildings of a single phase. On the other hand, depending on the depth and the coverage by demolition débris, the foundation walls of buildings appear only in a blurred manner. Some of the ancient features are probably multi-layered and covered by large layers of débris (see the yellow zone in fig. 8). Since the magnetic field in general is a potential field, the magnetogram of such areas as a matter of course reveal a more complex and indistinct result that is utterly impossible to interpret in a simple and singular manner.

In the surroundings of the Forum basilica, the data seemed to be disturbed by layers of débris caused by earlier excavations. However, to judge by the accompanying magnetic susceptibility measurements, it turned out that these disturbances are due either to the diamagnetic properties of the marble and quartz rocks or to the stone slabs with high magnetic qualities that were used to construct the basilica. Susceptibility measurements display even "negative" Kappa values (fig. 6), which is probably the reason for these "ferrimagnetic like" strong anomalies in the magnetometer data.

Throughout the area there are a few extremely strong magnetic anomalies that are indicative of intensive firing or burning. This is probably related to the relocation in late

11 J. W. E. Fassbinder, "Geophysical prospection of the frontiers of the Roman empire in southern Germany, UNESCO World Heritage Site," Archaeological Prospection 17 (2010) 129-39; "Geophysikalische Prospektion in Pompeiopolis," Schriften des Zentrums für Archäologie und Kulturgeschichte des Schwarzmeerraumes 21 (2011) 17-27. 


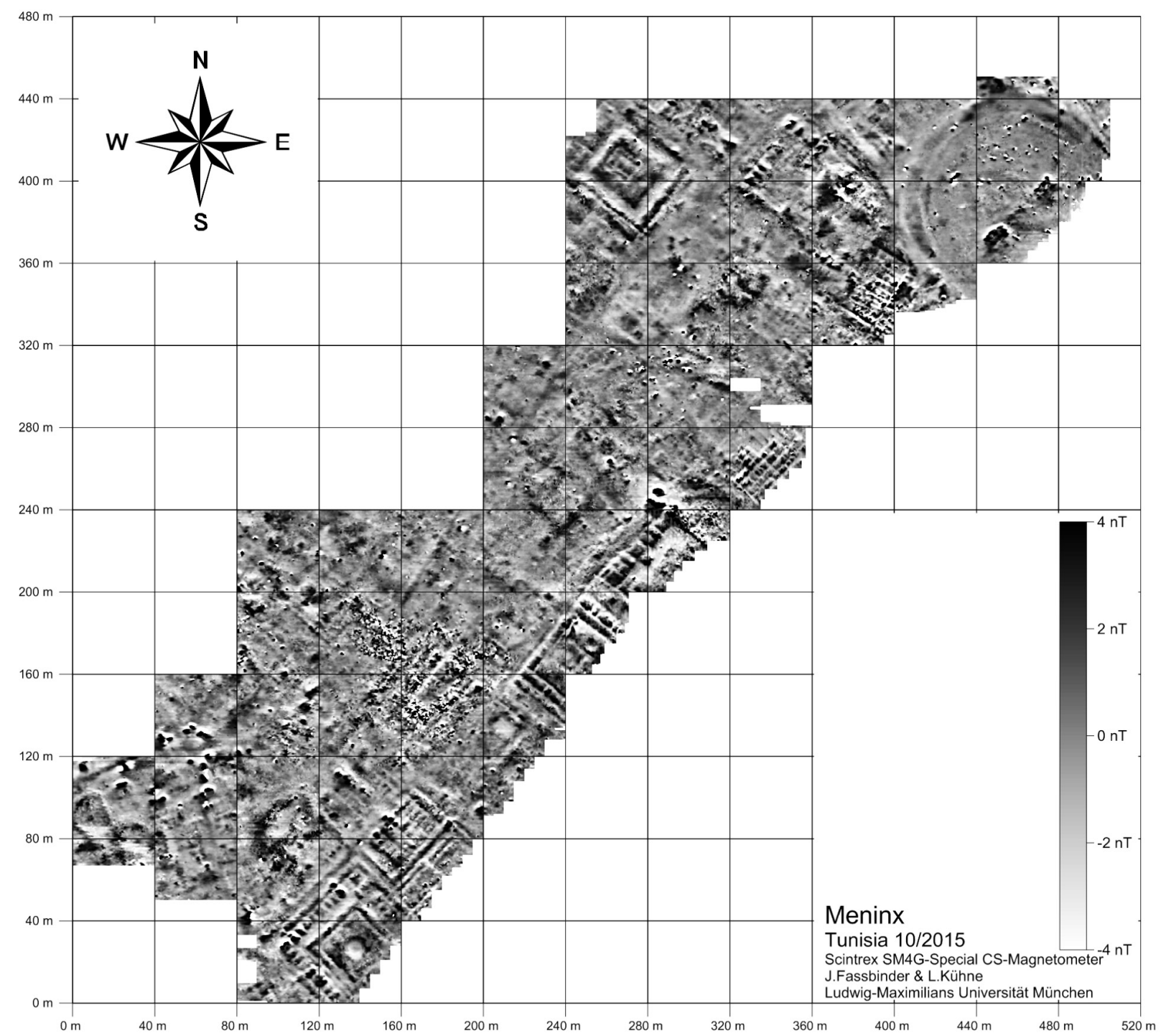

Fig. 7. Meninx, magnetogram of the site as a grey shade plot. Cesium-Smartmag SM4G-special-magnetometer, duosensor configuration, sensitivity $\pm 10 \mathrm{pT}$, sampling interval $12.5 \mathrm{x} 50 \mathrm{~cm}$ interpolated to $25 \mathrm{x} 25 \mathrm{~cm}$ in a 40-m grid. Total field values were reduced to the mean value of a $40 \mathrm{~m}$ square and fused by a high-pass filter magnetogram, with dynamics $\pm 4 \mathrm{nT}$ from black to white.

antiquity of production facilities to the center of the city. ${ }^{12}$ Overall, the magnetogram provided a clear and coherent plan of the city's centre.

\section{New insights into the urban layout of Meninx}

The road system

First, the magnetometer data provided us with clear insights into the road system (fig. 9 in colour). The central area of the city is crossed by two main roads which run roughly parallel to the coastline. The southeastern main road, closer to the coast, leads from the

12 For this phenomenon, which is indicated by the extent of the huge dumps of murex shells in previously inhabited urban areas from the 4th c. A.D. onwards, see Jerba Studies 1, 133-34. 
southwest into the area we prospected, passes the front of the macellum and the rear of the Forum basilica, and terminates at the cavea of the theatre. The northwestern main road runs between 60 and $90 \mathrm{~m}$ farther inland, entering the area we prospected from the northeast to lead directly to the Forum square. This road probably has to be regarded as the cardo maximus. Contrary to the earlier assumption that the main roads are parallel to each other (cf. fig. 3), ${ }^{13}$ it turns out that the city was not laid out within an orthogonal grid. The main roads are not straight but converge slightly towards the Forum; the streets which cross them, running towards the coast, bend slightly and/or end at one of the two main roads.

The two main roads divide the area we investigated into several urban zones which differ from one another in their general layout. At the southwest, the Forum and its surrounds form their own urban space. The remaining area is divided by the main roads into three zones, which are set out parallel to the coastline and structured in different ways.

\section{The Forum zone}

Around the Forum, where only the basilica was known hitherto, ${ }^{14}$ some other surrounding buildings are now visible. In 2000, T. Morton had already assumed that a temple ("south temple") lay beneath the high hill in the SE part of the Forum because of the large marble architectural fragments lying around there (fig. 10). ${ }^{15}$ Our prospection revealed the massive external walls of a rectangular $(c .40 \times 30 \mathrm{~m})$ building. Its interior structure is not clearly visible but a temple is quite probable, to judge by the architectural evidence. As its front is roughly parallel to the civic basilica, it is obvious that these two buildings, with some other structures between them, framed the Forum square on its long SE side.

To the southwest of the Forum square, another monumental structure, a large elongated $(c .55 \quad \mathrm{x}$ $35 \mathrm{~m})$ complex, has

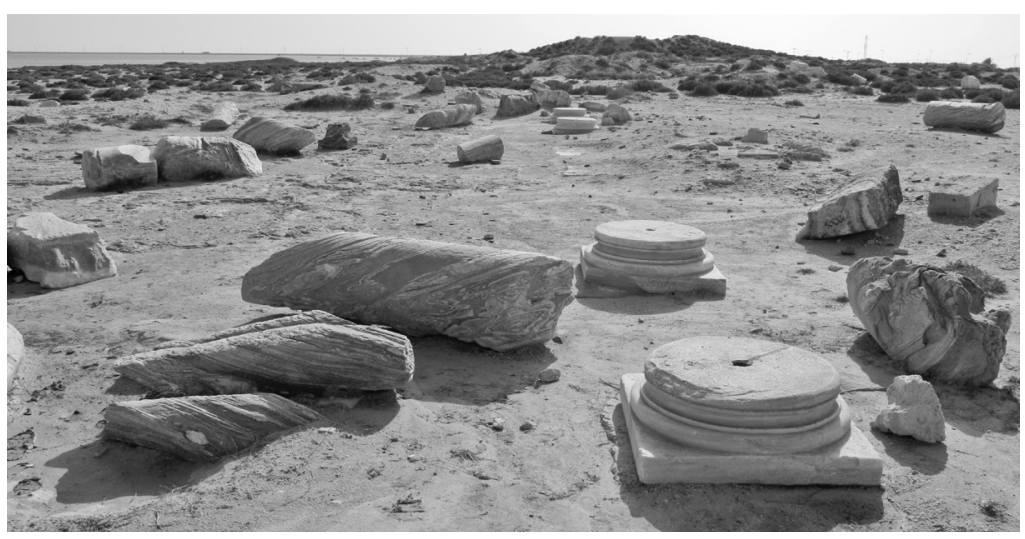

Fig. 10. Meninx, Forum, towards southwest, with 'South Temple' hill in the background (S. Ritter, 2013).

become visible. Its W (rear) part lies beneath a hill of débris where some marble architectural fragments lie scattered. They again led Morton to presume a temple ("southwest temple"), here at some distance from the Forum. ${ }^{16}$ The magnetogram is not very clear, however, so that the identification of the building must be left open, as is the question of how it related to the Forum square.

13 T. Morton, The impact of luxury: the Forum of Meninx - an architectural investigation (Ph.D. diss., Univ. of Pennsylvania 2003) 114-15; Jerba Studies 1, 157 with fig. 10.3.

14 For the basilica, see Morton ibid. 79-98; Jerba Studies 1, 138-45.

15 Morton ibid. 98-101; Jerba Studies 1, 145-47 with figs. 10.16-10.19. Morton (ibid. 145) proposed identifying this temple as the Capitolium because of the size of the architectural elements.

16 Morton ibid. 101-3; Jerba Studies 1, 148-49 with figs. 10.22. Morton (ibid. 148) assumed that this temple was situated "some $60 \mathrm{~m}$ southwest of the forum square". 
Another temple can be identified at the NW side of the Forum where Morton already presumed a temple ("north temple"). ${ }^{17}$ This building has now become clearly visible. Its front is roughly parallel to the basilica on the opposite side of the square. This sanctuary $(c .30 \times 25 \mathrm{~m})$ consists of an enclosed courtyard and a small temple set against the rear wall of the court.

The location of at least two temples that, like the basilica, framed the Forum indicates that the Forum square was $c .40 \mathrm{~m}$ wide and at least $90 \mathrm{~m}$ long. This is larger than was previously assumed. ${ }^{18}$ Its elongated shape is quite unusual in Proconsularis, the closest parallel in length and proportions being that at Utica (c.54 by at least $110 \mathrm{~m}) .{ }^{19}$ The Forum of Meninx also has some similarities to the Forum at Sabratha (see fig. 13 below).$^{20}$ In both cases the basilica lies on the long SE side of the square and both buildings are very similar in size and structure. ${ }^{21}$ Both squares are surrounded by several temples of different types, including the courtyard temple type, but at Meninx the arrangement of the buildings around the square and the shape of the Forum are quite different. Sabratha has a rectangular square with parallel porticoes on the long sides, and the surrounding buildings are axially related to one another; further, the square is separated from the surrounding areas and accessible at its corners. The Forum at Meninx, by contrast, has an elongated and slightly irregular shape, and it is a relatively open space, crossed by approach roads leading directly to the square.

\section{The coastal zone}

The coastal zone, between the modern coast and the southeastern main road, was occupied by monumental buildings, the seaward parts of which lie beneath present sea level which here, as elsewhere on the Tunisian coast, has risen since antiquity by between 50 and $75 \mathrm{~cm} .{ }^{22}$ The only coastal buildings known hitherto were the 'horrea' and macellum at the south and the very large theatre at the north (see fig. 3). ${ }^{23}$ Our magnetometer data now reveals that the whole area between the macellum and the theatre was occupied by further large buildings, separated from each other by roads leading off the main road towards the sea (see fig. 9). They obviously include several storage buildings, one of which is very closely linked to the macellum (fig. 11). The two neighbouring buildings, placed at the end

17 Morton ibid. 104-5; Jerba Studies 1, 148.

18 Jerba Studies 1, 137, where a size of $c .36 \times 70 \mathrm{~m}$ was assumed. Based on two marble bases, Morton (ibid. 147-48) proposed to identify a fourth temple ("West Temple") under the mounds on the NW side of the Forum. In this area, our magnetometry revealed only two long walls at rightangles to each other, which probably form the E corner of a greater building.

19 S. Ben Baaziz, "Les forums romains en Tunisie. Essai de bilan," in Los foros romanos de las provincias occidentales (Madrid 1987) 221-36. especially 223 (an overview Table) and 233 (for Utica, with earlier bibliography).

20 For the Forum of Sabratha, see P. M. Kenrick, Excavations at Sabratha 1948-1951 (London 1986) 7-117; J.-M. Blas de Roblès, Libye grecque, romaine et byzantine (Aix-en-Provence 1999) 42-47.

21 Jerba Studies 1, 144.

22 D. L. Stone, "Africa in the Roman empire: connectivity, the economy and artificial port structures," AJA 118 (2014) 573.

23 Jerba Studies 1, 150 (theatre), 153-55 ('horrea'), 155-57 (macellum). The huge complex south of the macellum, partially excavated between 2000 and 2006, consists of a long narrow paved court (or street) framed by porticoes with rows of narrow rooms behind them. It has been interpreted as horrea by the excavators: A. Drine, "Les entrepôts de Méninx," AntAfr 43 (2007) 240-49; Jerba Studies 1, 153-55 and 222-29. By April 2016 E. Fentress doubted this interpretation, arguing in favour of a colonnaded street framed by shops. 


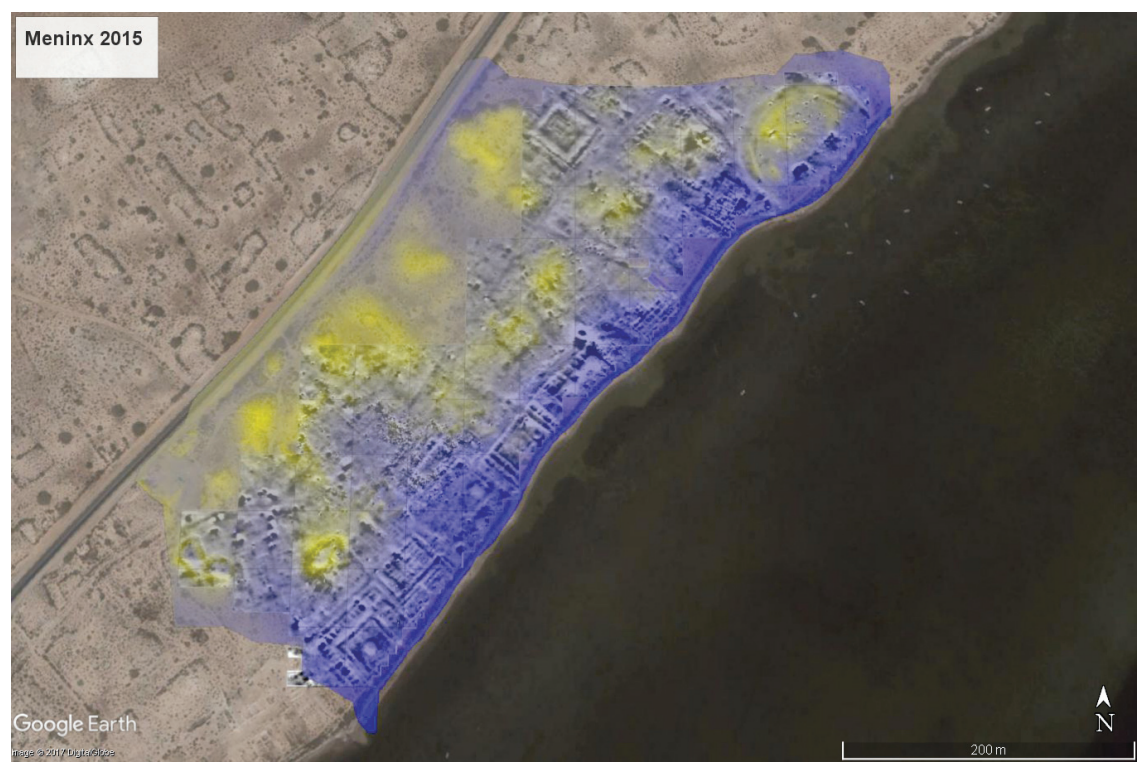

Fig. 8. Meninx, satellite image overlaid by the contour map and by the interpretation of the magnetometer data. The yellow parts mark the sectors with hills of débris; the blue are flat areas with distinct archaeological features.

Fig. 9. Meninx, magnetogram with preliminary results of the archaeological interpretation. 1: Southeastern main road. 2: Northwestern main road. 3: Forum. 4: Basilica. 5: 'South Temple'. 6: 'Southwest Temple'(?). 7: 'North Temple'. 8: 'Horrea'. 9: Macellum. 10: Storage building(?). 11: Temple. 12. Cistern complex. 13: Theatre. 14: Temple.






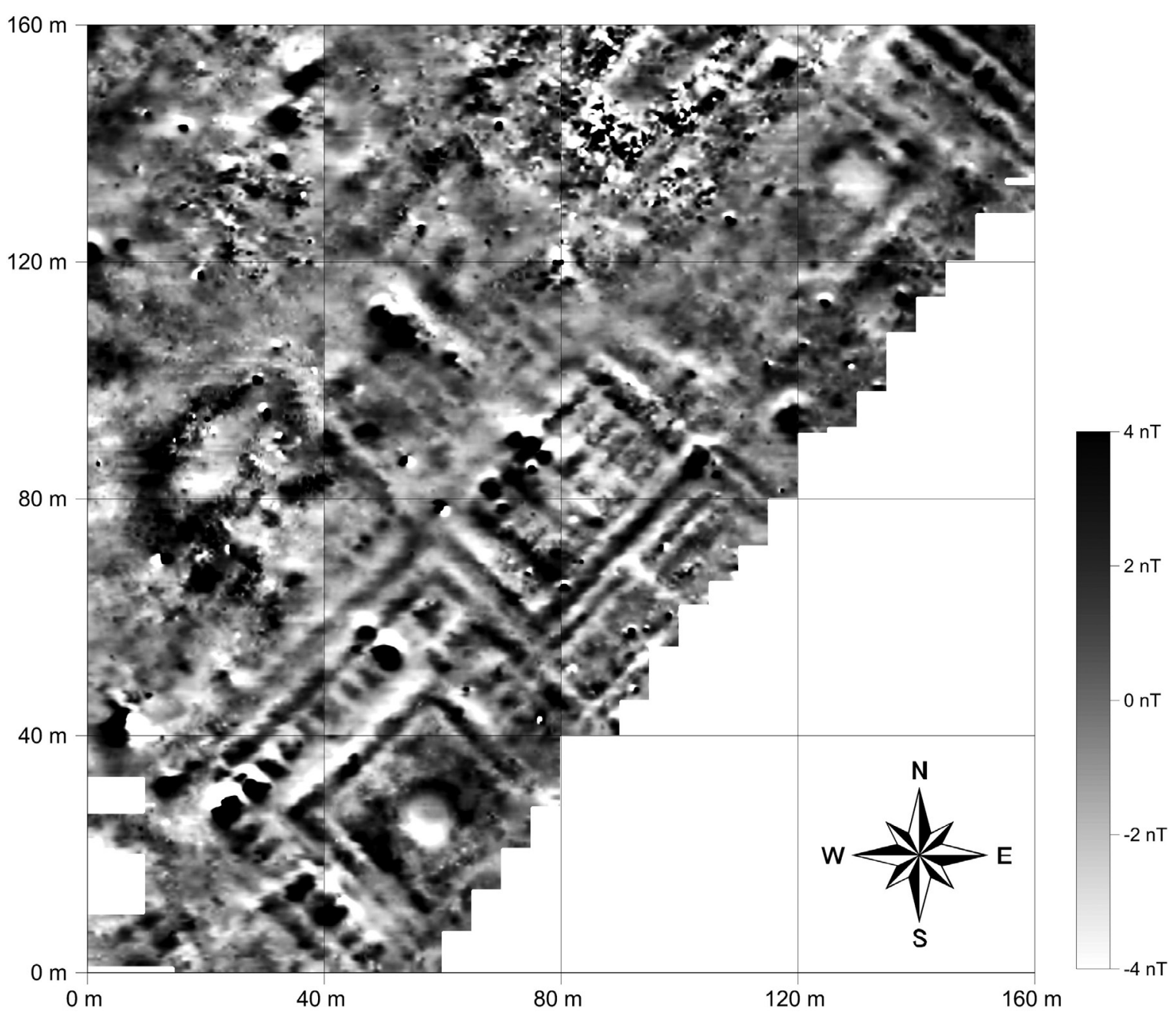

Fig. 11. Meninx, magnetogram, detail with the macellum.

of a cross road leading down from the Forum, have a common access from the main road, implying that this should be a storage complex, functionally linked to the macellum.

Some $70 \mathrm{~m}$ north of this complex, the magnetometry revealed another monumental building, the internal walls of which enclose an open space $c .30 \mathrm{~m}$ wide. Within this courtyard a small building is set against the rear wall. It should be a sanctuary of the courtyard temple type, oriented towards the sea. The next complex to the north, $c .60$ wide, also seems to be arranged around a central court, but it is quite irregular in shape and its structure is not very clear from the magnetometry. Farther north again is a complex consisting of 6 huge parallel cisterns (previously excavated), with another group of small cisterns farther to the northwest. ${ }^{24}$ As the magnetometry revealed, these groups of cisterns form part of a much larger (c.40 m wide, at least $50 \mathrm{~m}$ long) building complex of unknown function.

\section{The northwestern zones}

The area between the two main roads from the Forum basilica to the theatre is between 65 and $90 \mathrm{~m}$ wide. The area is rather irregular, with buildings of different size, shape and 


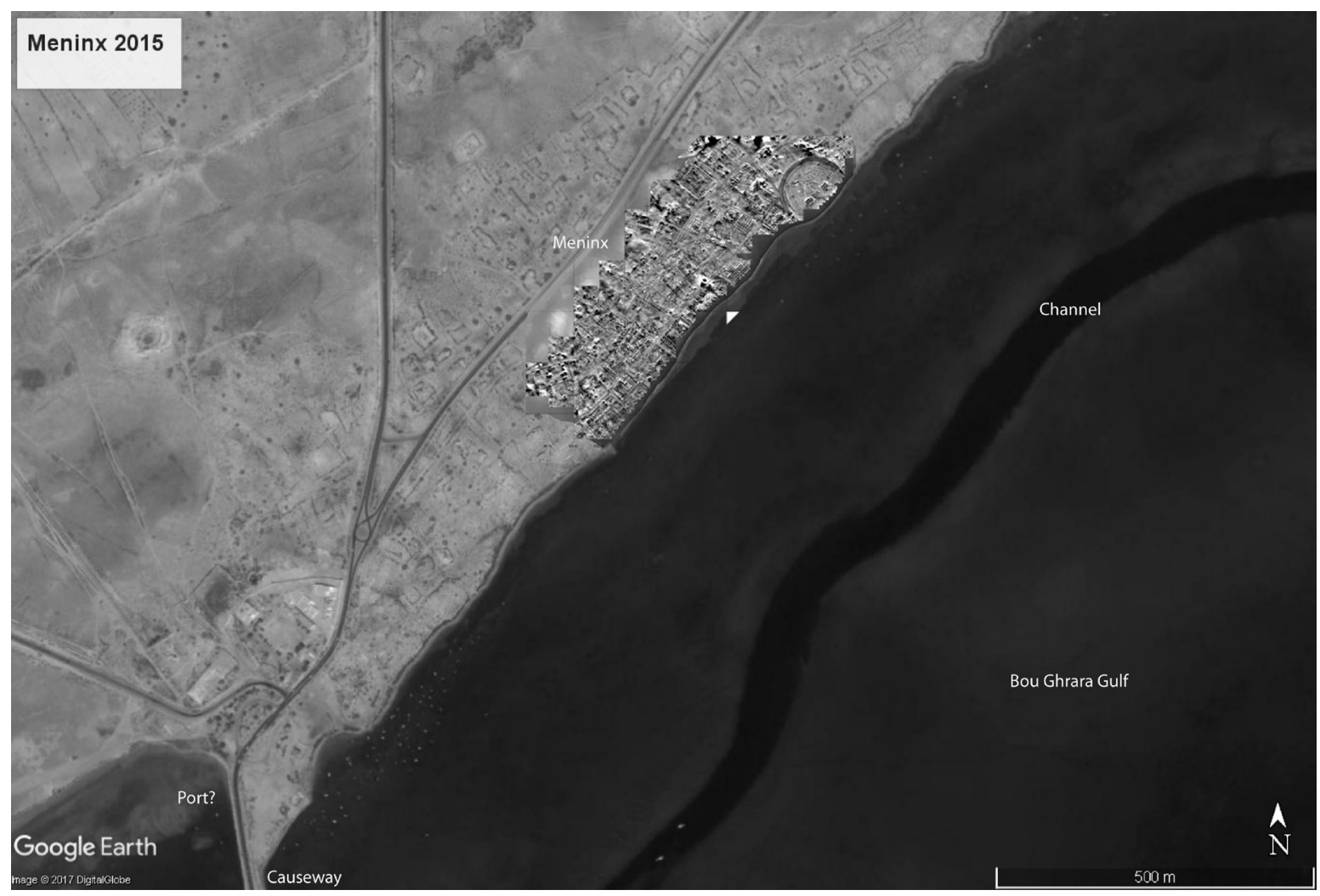

Fig. 12. Meninx, magnetometer plan plotted in Google Earth.

orientation. Within the definable units, groups of small rooms and some square interior courtyards can be distinguished, suggesting that the area was dominated by housing.

The zone at the NW end extending northwestwards from the inner main road could be investigated only partially due to the presence of the modern coastal road, but it seems to have had a somewhat more regular layout. Quite regular insulae are separated by small, roughly parallel crossroads. In the level area at the north a temple complex emerges as an almost square courtyard enclosed by porticoes and a three-cella temple set against the rear wall in such a way that it was oriented towards the sea. A round structure set precisely in front of the main cella is probably an altar.

\section{Comparisons with Sabratha and Lepcis Magna}

The irregular layout indicates that the city's appearance in late antiquity, which is what is visible in the magnetometry, was the result of a long-term urban development. The reshaping of earlier buildings can be seen most clearly in the Forum area, which received its final shape from the early 2 nd c. A.D. onwards, ${ }^{25}$ and as well in the row of monumental buildings along the present coastline. By analogy with other cities in N Africa, it is probable that the large buildings along the coast, from the macellum to the theatre, were constructed predominantly during the 2 nd and early 3rd c., in roughly the same period when the Forum was redesigned through the erection of new temples and other buildings. 

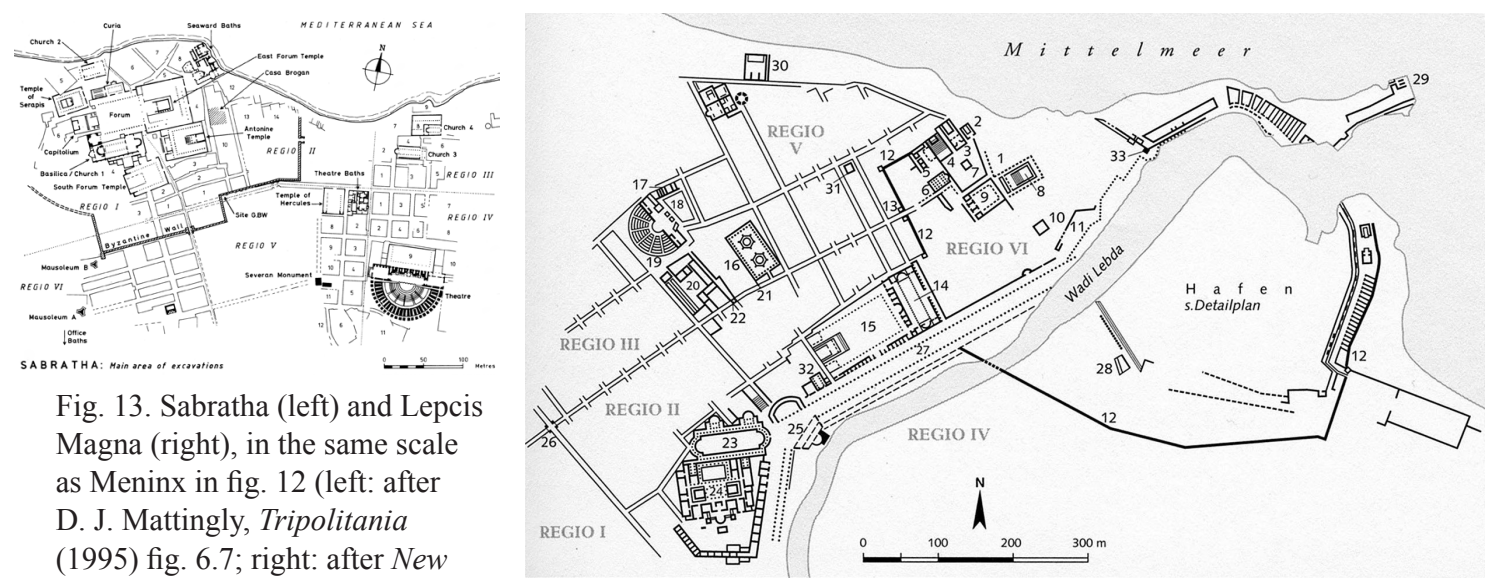

Fig. 13. Sabratha (left) and Lepcis Magna (right), in the same scale as Meninx in fig. 12 (left: after D. J. Mattingly, Tripolitania (1995) fig. 6.7; right: after New Pauly7 (1999) 77-78 (W. Huß).

The particularities of Meninx become evident when we compare its layout with the most important coastal cities of Tripolitania (figs. 12-13). There are several similarities in layout. ${ }^{26}$ In all three, the Forum (in the case of Lepcis Magna, the Old Forum) lies not far from the coast. In all three, the major arterial roads of the city centre converge slightly to the Forum area. The theatres are of roughly the same size, oriented towards the sea. ${ }^{27}$ Each city has the customary public buildings, including several temples, some of which surround the Forum while others are distributed throughout the city.

Yet Meninx differs from the two other port cities in the distribution of its monumental buildings and in its overall layout. In contrast to Sabratha and Lepcis Magna, its theatre is not located at a distance from the coast. The same applies to the macellum, in contrast to that of Lepcis Magna, which is placed inland and near the theatre. At Sabratha as well as at Lepcis Magna the main roads lead towards the sea, but at Meninx they run parallel to the coast, their orientation corresponding to the elongated shape of the Forum square.

The most distinctive feature of Meninx's urban layout is its extension along the coast, which was obviously due to two factors: its geographical situation and its economic character. In contrast to port cities such as Sabratha or Lepcis Magna, Meninx's immediate hinterland was covered by saline mudflats, unusable for agricultural purposes. ${ }^{28}$ Thus nowhere did the city extend more than $500 \mathrm{~m}$ inland, instead expanding for more than $1.5 \mathrm{~km}$ along the coast. Economically, Meninx was oriented towards the sea. The shallow coastal waters provided fish and, above all, murex for the purple dye industries, its most important economic sectors. ${ }^{29}$ Those sectors and their need for an adequate commercial infrastructure are obviously the main reason why a number of monumental buildings were set out in a row not far from the ancient coastline.

For Sabratha, see A. Di Vita, G. Di Vita-Evrard and L. Bacchielli, La Libye antique. Cités perdues de l'Empire romain (Paris 1998) 146-81, with plan on 148; Blas de Roblès (supra n.20) 37-59. For Lepcis Magna, see Di Vita, Di Vita-Evrard and Bacchielli ibid. 44-145, with plan on 51; Blas de Roblès ibid. 61-90.

F. Sear, Roman theatres. An architectural study (Oxford 2006) 281-82 (Lepcis Magna) and 283-84 (Sabratha). According to the magnetometry, the theatre of Meninx has a cavea diameter of c.100$105 \mathrm{~m}$, with the result that it would be larger than the theatres of Lepcis Magna (diam. $87.60 \mathrm{~m}$ ) and Sabratha (diam. $92.60 \mathrm{~m}$ ) and come close to that of Carthage (diam. c.104 m) (Sear 277-78). Jerba Studies 1, 75 and 207. 
The axial alignment of these buildings with the sea, and especially the unusual positioning of the theatre, point to an additional motivating factor that refers to the city's appearance from the sea. As T. Morton has recently demonstrated by creating a digital model of the coastal frontage of Roman Carthage, ${ }^{30}$ some coastal cities of Africa Proconsularis chose to align their civic projects with the sea, with the intention of creating an attractive urban image from there. In this regard, the situation at Meninx is very similar to that at Carthage. ${ }^{31}$ The alignment of a greater number of monumental buildings along the coastline is the most characteristic feature of the urban layout of Roman Meninx and must have given the city a particularly impressive skyline when viewed from the sea.

\section{Further research planned}

Starting from the surroundings of the Forum where the earliest settlement was located, we will conduct excavations in and around selected sanctuaries, commercial buildings and houses. We are particularly interested in the early settlement layers in order to gather information about the still-largely-unknown history of Meninx before it received a largely new design from the early or mid-2nd c. A.D. onwards. We also intend to extend the geophysical prospection to the city's peripheral quarters.

We then intend to conduct targeted underwater exploration (for the first time at Meninx) in order to investigate structural remains off the modern shore, which should include harbor structures. An underwater survey is the only way to gain information about the town's port facilities. At present it is unclear where the port mentioned in written sources was situated. ${ }^{32}$ It has been suggested that it lay in the small bay south of Meninx, at the start of the causeway leading to the mainland, where a row of large blocks visible underwater has been interpreted as a jetty (see fig. 12). ${ }^{33}$ However, the water in the Bou Ghrara Gulf is very shallow, and was even more so in antiquity, making access from the sea difficult. The only opportunity for larger ships to approach the city was by some broad and deep submarine channels. The largest among those (5-7 m deep, varying from 50 to $200 \mathrm{~m}$ in width) is the Wadi al-Kabir, which leads from the open sea into the Gulf and after some $9 \mathrm{~km}$ terminates in the middle of the causeway. ${ }^{34}$ The channel next to Meninx, which is the largest and deepest, splits off to the right from Wadi al-Kabir towards Meninx, before turning southwest and running for a distance of $c .2 \mathrm{~km}$ parallel to the coast of the city at some 300 to $400 \mathrm{~m}$ from the modern coastline, but it does not reach the bay where the port has been assumed to lie. These channels are critical for answering the question of where Meninx's port facilities were situated. Larger boats could approach the city only by way of the submarine channels and therefore had to navigate at a greater distance from the shore, with

30 T. Morton, "The importance of the sea for the urban armature in Roman Carthage," in D. Favro, F. Yegül, J. Pinto and G. Métraux (edd.), Paradigm and progeny: Roman imperial architecture and its legacy (JRA Suppl. 101, 2015) 123-36 with figs. 3-5 and 7-9. At Carthage, this intention is primarily indicated by the unusual positioning and overwhelming scale of the Antonine Baths (ibid. 128-30).

31 As Morton has pointed out (ibid. 127 with n.225), the resolute alignment of civic projects with the sea did not serve as an organizing principle of all coastal cities in Roman Africa: "Lepcis Magna, for example, had a series of organizing systems, some of which were not related to the coast".

32 Stadiasmus Maris Magni 103; see Jerba Studies 1, 40 Table 3.1, no. 16.

33 Jerba Studies 1, 45-46 and 157; Stone (supra n.22) 574.

34 Jerba Studies 1, 58. 
the effect that those arriving from the sea would have experienced Meninx's monumental seascape from afar, as part of a slow process of revealing the city's major public buildings.

Our interdisciplinary investigations will continue to explore the extent to which the cultural geography and the particular economic rôle of Meninx are reflected in the urban structure. Hopefully, this work will fill the gap between the cities on Tunisia's E coast, from Kerkouane to Gigthis, and those of Tripolitania (Sabratha and Lepcis Magna) by better understanding the important rôle that Meninx played as an epicenter between Mediterranean trading networks and the nearby mainland with its trading routes from and into the Sahara. ${ }^{35}$

SR Institut für Klassische Archäologie, Ludwig-Maximilians-Universität München. SBT Institut National du Patrimoine, Tunis / Jerba $\mathrm{JF}$ Department für Geo- und Umweltwissenschaften der LMU/ \& Bayerisches Amt für Denkmalpflege LL Institut für Klassische Archäologie, LMU/Faculty of Archaeology, Leiden University

\section{Acknowledgements}

The October 2015 magnetometer survey was conducted by Sami Ben Tahar, Stefan Ritter, Jörg Fassbinder, Lena Kühne, Dennis Beck (Freie Universität Berlin), Sebastian Graf, Julian Pimpi (both of the TU München, Lehrstuhl für Geodäsie), Olfa Souissi, Marwan Ben Ibrahim, Riadh Ben Ibrahim (all of the Université de Tunis), and Rhoma Abdjli (INP). We wish to thank the Deutsche Forschungsgemeinschaft and the Bayerische Akademie der Wissenschaften for having funded the project in 2015. Further information and more images can be found on the project's website: http://www.klassarchaeologie.uni-muenchen.de/forschung/projekte1/d-projekte-laufend/meninx/index.html 